\title{
Mucoepidermoid carcinoma of the penis: Case report and literature review
}

\author{
Márcio Rodrigues Costa, MD; ${ }^{*}$ Denis Masashi Sugita, MD; ${ }^{\dagger}$ Maria Helena Tavares Vilela, MD; ${ }^{\dagger}$ \\ Rodrigo Pastor da Silva Mendonça, MD;" Danilo Tavares Maranhão de Morais, MD;" \\ Paulo Cézar Ribeiro Gomes Júnior, MD, Théo Rodrigues Costa, MD, Bernardo Monteiro Antunes Barreira, MD*
}

*Division of Urology, Department of Surgery, Hospital das Clinicas, Federal University of Goíás Medical School, Goiânia, GO, Brazil; 'Division of Pathology, Department of Pathology, Radiology and Imaging Diagnostic, Hospital das Clinicas, Federal University of Goiás Medical School, Goiânia, GO, Brazil

Cite as: Can Urol Assoc J 2015;9(1-2):E27-9. http://dx.doi.org/10.5489/cuai.2126

Published online January 12, 2015.

\section{Abstract}

We describe the fifth case of mucoepidermoid carcinoma. The patient had penile ulcer with bilateral inguinal and pelvic lymphadenopathy and underwent total penectomy. After antibiotic therapy, the patient began outpatient chemotherapy, but the treatment was discontinued due to his intolerance. The patient died due to infectious complications of the inguinal lymphatic fistula 7 months after the histological diagnosis. Notably, the periurethral area was involved in the anatomopathological evaluation of the excised penis. The penile mucoepidermoid carcinoma was aggressive and the perimeatal region was involved. This case helps demystify the origins and prognosis of this rare case. More reports documenting patient characteristics and their evolution with penile mucoepidermoid carcinoma are needed.

\section{Introduction}

Squamous cell carcinoma (SCC) accounts for 95\% of the histological types of penile cancer, ${ }^{1}$ but other rarer types, such as mucoepidermoid carcinoma (MC), may also affect the penis. The origin of SCC of the penis is usually the scamous epithelial surface, while the MC of the penis does not have a known source. Glans cancer frequently arises from the periurethral glands of Littré, bulbar Cowper, and sweat glands. ${ }^{2-4}$

The prognosis of penile cancer in its early stages is good. The survival and the risk of metastasis of SCC of the penis are different according to histologic variants. The histological subtypes verrucous, papillary, and verrucoid are low risk, and the usual SCC is intermediate risk and the sarcomatoid or basaloid variants are high risk. ${ }^{5}$ Although non-SCC types are not classified in risk, their behaviour and prognosis can be ascertained. Basal cell carcinomas are highly curable and have a low potential for metastasis; they are prone to local recurrence, but metastases are rare and the melanomas are aggressive but can be cured if treated early. ${ }^{6}$ The adenosquamous carcinoma is locally aggressive, with high histologic grade differentiation at diagnosis and a high rate of lymphovascular invasion. ${ }^{7}$ It well-known that, generally, metastatic tumours to the penis have a poor prognosis. ${ }^{6} \mathrm{MC}$ of the penis is extremely rare and has a pattern of behavior has not yet been established.

We used 4 databases for our analysis (PubMed, Portal de Periódicos da Capes, Lilacs, and SciELO) on February 17,2014 . We searched without filtres and with the intersection of the following MESH terms: "Penile neoplasms" versus "Mucoepidermoid Tumour" or "Carcinoma, Mucoepidermoid" and "Penis" versus "Mucoepidermoid Tumor" or "Carcinoma, Mucoepidermoid." In doing so, we identified 4 cases of primary penile MC (Table 1). This is the fifth case, which adds to the literature and helps delineate the behaviour and origin of this disease.

\section{Case report}

Our patient, a 47-year-old had a wound on the penis after circumcision. He sought medical attention 45 days after lesion onset; it was a single lesion, showing ulcerative and infiltrative aspect, about $7 \mathrm{~cm}$, occupying the entire glans and about four-fifths of the distal penile shaft (Fig. 1). Physical evaluation of inguinal region showed multiple and bilateral lymphadenopathy. The patient was underwent biopsy of the penile lesion with microscopic examination compatible to MC. Computed tomography of abdomen demonstrated multiple inguinal and pelvic lymphadenomegaly.

The patient underwent perineal urethrostomy and total penectomy. Upon pathologic evaluation, the penis length was $7.8 \mathrm{~cm}$, with the lesion occupying the distal portion of the penile shaft and involving the periurethral area of the glans. The cut surface of the tumour showed heteroge- 


\begin{tabular}{|c|c|c|c|c|c|}
\hline Author & Shrikhande and Sirsat ${ }^{9}$ & Froehner et al. ${ }^{1}$ & Layfield and Liu ${ }^{10}$ & Warnnissorn et al. ${ }^{8}$ & Current case \\
\hline Publication year & 1974 & 2000 & 2000 & 2003 & 2015 \\
\hline Patient age, years & 40 & 63 & 55 & 31 & 47 \\
\hline $\begin{array}{l}\text { Lesion time before } \\
\text { treatment }\end{array}$ & 1 year & 21 days & Not specified & 1 year & 45 days \\
\hline $\begin{array}{l}\text { Primary lesion } \\
\text { localization }\end{array}$ & Almost entire penis & Balano-preputial & $\begin{array}{l}\text { Distal penile including } \\
\text { urethral meatus }\end{array}$ & $\begin{array}{l}\text { Glanular including } \\
\text { periurethral area }\end{array}$ & Periurethral area \\
\hline Lymphadenopathy & Inguinal and bilateral & Not Specified & Absent & $\begin{array}{l}\text { Inguinal and } \\
\text { bilateral }\end{array}$ & Pelvic \\
\hline Conduct & $\begin{array}{l}\text { Emasculation and } \\
\text { inguinal lympha- } \\
\text { denectomy }\end{array}$ & $\begin{array}{l}\text { Excision and } \\
\text { coagulation of } \\
\text { the tumour bed }\end{array}$ & $\begin{array}{l}\text { Partial penectomy } \\
\text { and inguinal lympha- } \\
\text { denectomy }\end{array}$ & $\begin{array}{l}\text { Partial penectomy } \\
\text { and inguinal } \\
\text { lympha-denectomy }\end{array}$ & Total penectomy \\
\hline Evolution & Not specified & Local recurrence & $\begin{array}{l}\text { Absence of detectable } \\
\text { lesions }\end{array}$ & $\begin{array}{c}\text { Absence of } \\
\text { detectable lesions }\end{array}$ & $\begin{array}{l}\text { Death } 7 \text { months after } \\
\text { diagnosis, due to infectious } \\
\text { complications of the } \\
\text { inguinal lymphatic fistula }\end{array}$ \\
\hline Follow-up & 3 months & 52 months & 6 months & 3 months & Not applicable \\
\hline
\end{tabular}

neous and friable mass with brownish and whitish areas. Microscopically, about $90 \%$ of the lesion was represented by intraepithelial neoplasia of coalescing atypical blocks SCC, with cornea pearls and extensive areas of keratinization (Fig. 2). In 10\% of the lesion, we found anastomosing cords and trabeculae, formed by cells with predominantly dense cytoplasm, but with some areas showing vacuolated cytoplasm. The clear cells were stained with periodic acidSchiff diastase (Fig. 3), but were not true glandular formation. Carcinoma in situ, perineural or angiolymphatic invasion, involvement of sweat, Littré or Cowper's glands did not occur. The surgical margins were free. The histopathology was consistent with invasive MC.

The patient was discharged on postoperative day 2 and he was scheduled for outpatient antibiotic therapy for 8 weeks and chemotherapy (prior to bilateral inguinal and pelvic lymphadenectomy). However, the patient discontinued chemotherapy due to intolerance, after he experienced inguinal signs of inflammation and lymphatic fistula at the left

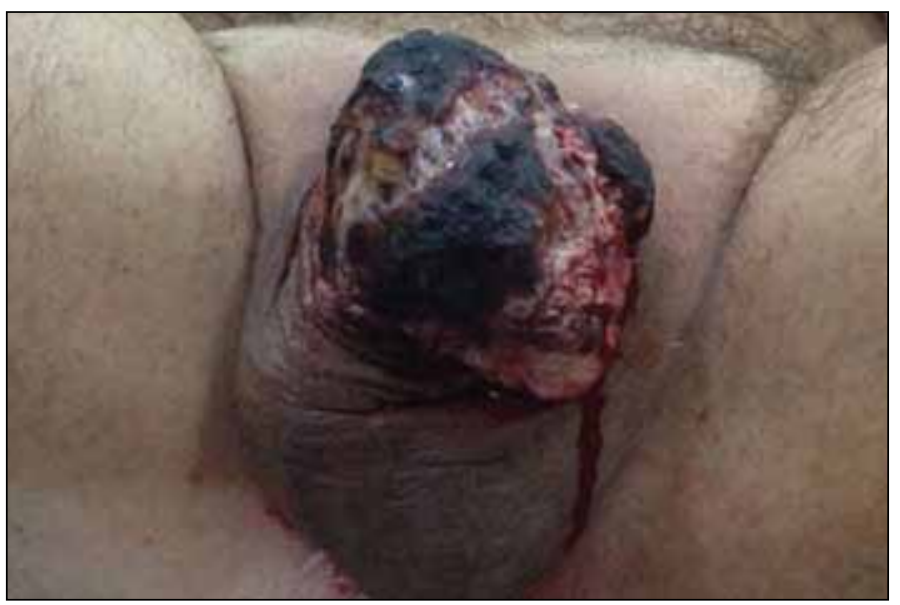

Fig. 1. Penile mucoepidermoid carcinoma. Giant ulcerated lesion. inguinal area. The situation was complicated by sepsis and the patient died 7 months after the histological diagnosis.

\section{Discussion}

Although MC is more frequently found in the salivary glands, some cases of this histological type have been described in the penis. ${ }^{8}$ The first case was reported in 1974, followed by 2 others in 2000 and 1 in 2003 (Table 1). This is the fifth case of this rare histological type.

Most penile skin tumours arise from squamous epithelium. Although the origin of MC in the penis remains unknown, some hypotheses have been suggested. Warnnissorn and colleagues ${ }^{8}$ suggest that malignant glandular cells in glanular epithelium can originate from aberrant differentiation of SCC; from the pluripotent stem of the region; or these cells can arrive in the glans through the misplacement of cells from the perimeatal in the embryologic period. Shrikhande

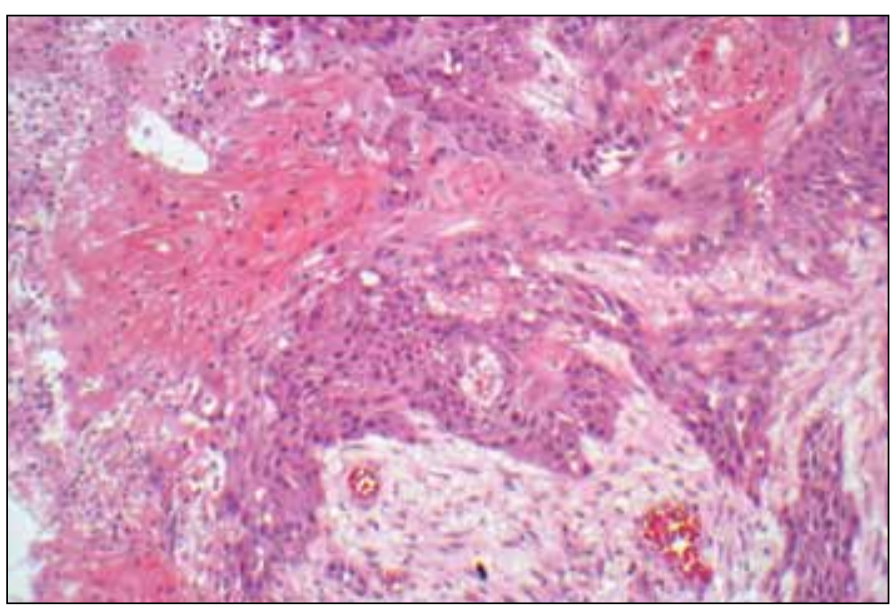

Fig. 2. Penile mucoepidermoid carcinoma. Well-differentiated and keratinized squamous component (Hematoxylin and eosin, original magnification 100x). 


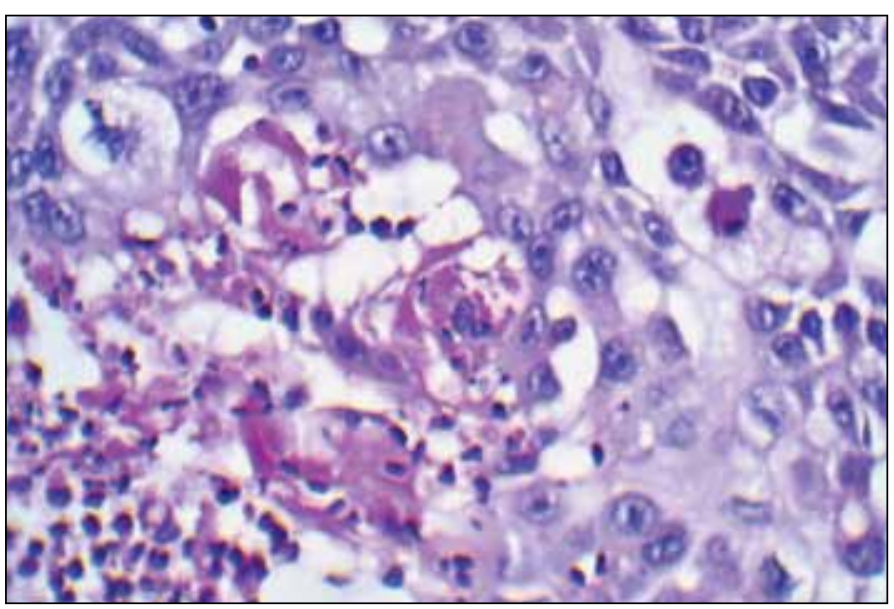

Fig. 3. Penile mucoepidermoid carcinoma. Intra- and extracellular positive staining and clear vacuolated cells (Periodic acid-Schiff-diastase, original magnification 400x).

and Sirsat ${ }^{9}$ suggested that MC may result from dual capability of differentiation of the columnar cells into SCC or mucous cells. For Froehner and colleagues, ${ }^{1} \mathrm{MC}$ results in the epithelial carcinoma of the penis that undergoes metaplastic changes or arises from misplaced sweat glands to the penis. Similar to Warnnissorn and colleagues, ${ }^{8}$ we found that the perimeatal region was involved and the absence of sweat, Littré or Cowper's glands was compatible with the hypothesis that MC is a bimodal cancer. The tumour originates in the glans, and the malignant cells come from the squamous epithelium and the glandular cells (mucin-producing) next to the navicular fossa regions.

The MC of penis has a poor prognosis. ${ }^{1,10}$ None of the 4 patients in the previous 4 cases died, yet they had advanced disease (Table 1). Lymph node involvement occurred in 3 out of 4 patients. Aggressive treatment as emasculation was done in 1 case and inguinal lymphadenectomy in 3 cases (Table 1). One patient had local recurrence as described by Froehner and colleagues. ${ }^{1}$ The absence of deaths can be explained by the minimal follow-up. Most patients were assessed up to 6 months or less and just 1 patient had a follow-up of 52 months (Table 1). Although in the present case, the pathology revealed well-differentiated squamous malignant cells, the disease was marked by rapid growth, early lymph node involvement and death 7 months after diagnosis. Therefore, we can suggest that MC of the penis has an unfavourable evolution and requires early and aggressive treatment compared to other histological types.

\section{Conclusion}

Our patient's penile MC was aggressive behavior and involved the perimeatal region. The knowledge of the evolution, prognostic and origin of this disease are in their initial stages. This case report adds to the literature. More details and longer term follow-up are needed to further clarify this disease.

Competing interests: Authors declare no competing financial or personal interests.

This paper has been peer-reviewed.

\section{References}

1. Froehner M, Schöbl R, Wirth MP. Mucoepidermoid penile carcinoma: Clinical, histologic, and immunohistochemical characterization of an uncommon neoplasm. Urology 2000;56:154.

2. Carpenter AA, Bernardo JR Jr. Adenoid cystic carcinoma of Cowper's gland. J Urol 1971;106:701.

3. Dobos El, Downing SW, Prather Ashe SM. Primary carcinoma originating in the Littré glands. Cancer 1954;7:539-48. http://dx.doi.org/10.1002/1097-0142(195405)7:3<539::AIDCNCR2820070313>3.0.C0;2-7

4. Mitsudo S, Nakanishi I, Koss L. Paget's disease of the penis and adjacent skin. Its association with fatal sweat gland carcinoma. Arch Pathol Lab Med 1981;105:518-20.

5. Cubilla AL, Reuter V, Velazquez E, et al. Histologic classification of penile carcinoma and its relation to outcome in 61 patients with primary resection. Int I Surg Pathol 2001;9:111-20. http://dx.doi. org/10.1177/106689690100900204

6. Pettaway CA, Lance RS, Davis JW. Tumors of the ienis. In: Kavoussi LR, Wein AJ, Novick AC, eds. Campbell-Walsh Urology. 10th ed. Philadelphia, PA; 2012:931. http://dx.doi.org/10.1016/B9781-4160-6911-9.00034-7

7. Cunha IW, Guimaraes GC, Soares $F$, et al. Pseudoglandular (adenoid, acantholytic) penile squamous cell carcinoma: A clinicopathologic and outcome study of 7 patients. Am J Surg Pathol 2009;33:551-5. http://dx.doi.org/10.1097/PAS.0b013e31818a01d8

8. Warnissorn N, Parichatikanond P, Ratanarapee $S$, et al. Two unusual primary carcinomas of glans penis: Mucoepidermoid carcinoma and adenosquamous carcinoma. Siriraj Hosp Gaz 2003;55:402-8.

9. Shrikhande SS, Sirsat MV. Muco-epidermoid carcinoma of the penis: Report of an unusual case. Br J Urol 1974;6:233-5. http://dx.doi.org/10.1111/j.1464-410X.1974.tb03748.x

10. Layfield LJ, Liu K. Mucoepidermoid carcinoma arising in the glans penis. Arch Pathol Lab Med 2000;124:148-51.

Correspondence: Dr. Mário Rodrigues Costa, Rua 15, número 87 / 802, Setor Oeste, Ed. Cotê D’or, Goiânia, G0, 74140-035, Brazil; marciorodriguescosta@bol.com.br 